\title{
The Distribution of Blood Flow, Oxygen Consumption, and Work Output among the Respiratory
}

\section{Muscles during Unobstructed Hyperventilation}

\author{
Charles H. Robertson, Jr., Michael A. Pagel, and Robert L. Johnson, Jr. \\ From the Pauline and Adolph Weinberger Laboratory for Cardiopulmonary Research, Department \\ of Internal Medicine, University of Texas Health Science Center at Dallas, Dallas, Texas 75235
}

A B S T RACT An animal model was developed to describe respiratory muscle work output, blood flow, and oxygen consumption during mechanical ventilation, resting spontaneous ventilation, and the increased unobstructed ventilatory efforts induced by $\mathrm{CO}_{2}$ rebreathing. Almost all of the work of breathing was inspiratory work at all ventilatory levels; thus, only blood flows to the diaphragm and external intercostals increased in the transition from mechanical to spontaneous ventilation, and they further increased linearly as ventilatory work was incrementally augmented ninefold by $\mathrm{CO}_{2}$ rebreathing. No other muscles of inspiration manifest increased blood flows. A small amount of expiratory work was measured at high ventilatory volumes during which two expiratory muscles (transverse abdominal and intercostals) had moderate increases in blood flow. Blood pressure did not change, but cardiac output doubled. Arterialvenous oxygen content difference across the diaphragm increased progressively, so oxygen delivery was augmented by both increased blood flow and increased oxygen extraction at all work loads. Oxygen consumption increased linearly as work of breathing increased, so efficiency did not change significantly. The mean efficiency of the respiratory muscles was $15.5 \%$. These results differ significantly from the patterns previously observed by us during increased work of breathing induced by inspiratory resistance, suggesting a different distribution of work load among the various muscles of respiration, a different fractionation of oxygen delivery between blood flow and oxygen extraction, and a higher efficiency when shortening, not tension development, of the muscle is increased.

Received for publication 28 April 1976 and in revised form 14 September 1976.

\section{INTRODUCTION}

Little is known about the partitioning of the work of breathing among the various primary and accessory muscles of respiration during quiet breathing or during differing types of ventilatory stress. An examination of the distribution of blood flow to each respiratory muscle should be an accurate way of determining the distribution of work, since blood flow to skeletal muscle is proportional to effort exerted by the muscle (1-5). Simultaneous measurements of arteriovenous oxygen content differences $\left(\mathrm{A}-\mathrm{V} \Delta \mathrm{CO}_{2}\right)^{1}$ should allow calculation of the oxygen consumption $\left(\dot{\mathrm{V}}_{\mathrm{O}_{2}}\right)$ of these muscles and an assessment of their efficiency.

The present investigation was designed to delineate the distribution of blood flow among, and oxygen consumption by, the respiratory muscles under three conditions: $(a)$ mechanical ventilation to assess basal metabolism $(b)$ resting ventilation, and $(c)$ the increased ventilatory efforts induced by $\mathrm{CO}_{2}$ rebreathing. The results of this study are compared to our previous observations during increased work of breathing induced by inspiratory resistance (1). The results suggest a different efficiency of and distribution of work load among the muscles of respiration when dynamic shortening instead of tension development is increased.

\section{METHODS}

Seven healthy mongrel dogs weighing $15-30 \mathrm{~kg}$ underwent a sterile thoracotomy $2-3 \mathrm{wk}$ before the experimental pro-

\footnotetext{
${ }^{1}$ Abbreviations used in this paper: $\mathrm{A}-\mathrm{V} \Delta \mathrm{CO}_{2}$, arteriovenous oxygen content differences; $\mathrm{QD}$, blood flow to the diaphragm; $\dot{Q} E$, blood flow to external intercostals; $\dot{Q R S}$, total blood flow to the muscles of respiration; $\mathrm{VO}_{2}$, oxygen consumption; $\dot{W}$, total rate of work of breathing.
} 


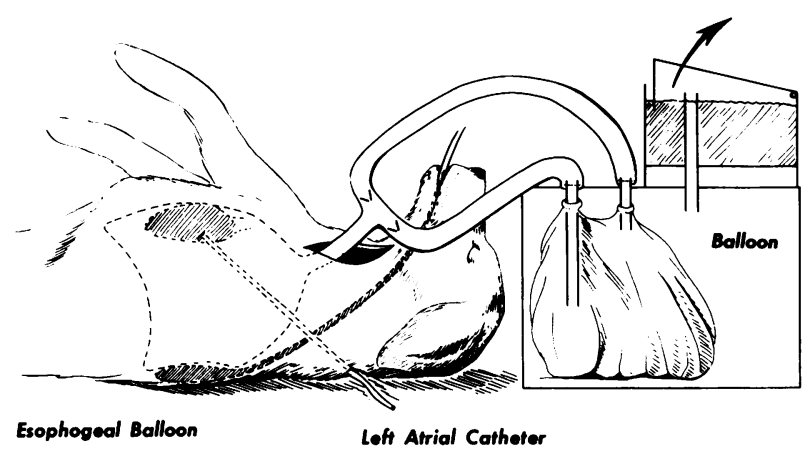

Figure $1 \quad \mathrm{CO}_{2}$ rebreathing study. Apparatus used to measure ventilation while the animal rebreathed from the balloon in the system. The left atrial catheter allows injection of microspheres for blood flow determinations and the esophageal balloon affords an index of pleural pressure.

cedure. An 18-gauge polyvinyl catheter was implanted into the left atrium through the left atrial appendage and exteriorized at the back of the neck.

During the experiment the dog was anesthetized initially with $25 \mathrm{mg} / \mathrm{kg}$ of sodium pentobarbital; at intervals additional pentobarbital was administered to sustain adequate anesthesia while maintaining the corneal reflex. A tracheostomy was performed and connected to an Otis-McKerrow valve. A balloon was positioned in the distal esophagus and inflated witn $1.0 \mathrm{ml}$ of air, which allowed accurate recording of external pressures from +50 to $-50 \mathrm{~cm} \mathrm{H}_{2} \mathrm{O}$; pressures were measured by a Statham PM131TC transducer (Statham Instruments Div., Gould Inc., Oxnard, Calif.). All measurements were made with the animal supine.

Initial studies were performed during mechanical ventilation with a Harvard pump (Harvard Apparatus Co., Inc. Millis, Mass.) at a minute volume which suppressed spontaneous ventilatory activity. Then studies were repeated with the animal at resting ventilation while connected to a rebreathing system (Fig. 1) which initially contained $50 \%$ oxygen $-50 \%$ nitrogen. Finally, measurements were made at approximately two- and fourfold increases in minute ventilation induced by the gradual buildup of the animal's expired carbon dioxide. Ventilation was monitored by a Krogh spirometer. In preliminary studies the rebreathing system was determined to have a flat amplitude response up to $7 \mathrm{cps}$. When sine wave volume signals were induced simultaneously into the box-spirometer system and into a rigid bottle containing the esophageal balloon, the box and balloon were in phase to at least 5 cps.

Esophageal pressure and box volume were recorded simultaneously on the electromagnetic tape of a Sanborn Ampex Model 2000 recorder (Ampex Corp., Redwood City, Calif.). From these recordings pressure and volume were converted to digital form and the mechanical pressure-volume work done on the lungs (6-8) was calculated by numerical integration with a computer as previously described (1). At each level of minute ventilation, work was calculated for each breath over a 5-min period and the average work per minute determined. Work was assumed to be zero when spontaneous respiratory efforts were suppressed by mechical ventilation.

Flow to each of the respiratory muscles was measured on mechanical ventilation and at each of three levels of spontaneous ventilation by a radioactive microsphere technique (9-12). The modifications and reproducibility of this technique for measuring respiratory muscle blood flow are presented in a separate communication (1). Since blood flow to skeletal muscle increases with work output by the muscle $(2-5)$, the respiratory muscles under the condition of $\mathrm{CO}_{2}$ rebreathing were assumed to be those whose flow increased. Total respiratory muscle blood flow was then calculated as the sum of flows to the utilized muscles.

To assess the contribution of changes in cardiac output to the changes in flows seen in the respiratory muscles during $\mathrm{CO}_{2}$ rebreathing, cardiac output was measured in a separate series of five similarly anesthetized dogs subjected to the same sequence of ventilatory stimuli. The indocyanine-green dilution method was used employing a Lyons model DCCO-04 computer (Physio-Tronics, Inc., Burbank, Calif.). Measurements were performed in triplicate and averaged.

In four animals a no. 7F catheter (ASCI 5423) was advanced under fluoroscopic control from the left femoral vein into the left inferior phrenic vein as described by Rochester (13). Proper positioning of the catheter was confirmed after completion of the experiment by dissection at autopsy. It has been demonstrated previously that catheters so positioned are not contaminated with inferior vena cava blood (13). At each work level simultaneous heparinized samples were withdrawn anaerobically from the diaphragmatic vein and femoral artery and analysed immediately for $\mathrm{P}_{\mathrm{O}_{2}}(313$ Blood Gas Analyzer, Instrumentation Laboratory, Inc., Lexington, Mass.), $\mathrm{O}_{2}$ saturation (Instrumentation Laboratory Cooximeter), and hemoglobin (Beckman DB Spectrophotometer, Beckman Instruments, Inc., Fullerton, Calif.). Arterial and venous oxygen contents were calculated and arteriovenous content difference determined for each run

Since the total respiratory muscle blood flow was known, the oxygen consumption of the muscles of respiration was calculated as the product of the total blood flow to all muscles $x$ the oxygen extraction across one of them,

TABLE I

Ventilatory Parameters

\begin{tabular}{|c|c|c|c|c|}
\hline & $\begin{array}{l}\text { Mechanical } \\
\text { ventilation }\end{array}$ & $\begin{array}{c}\text { Resting } \\
\text { ventilation }\end{array}$ & $\begin{array}{l}\text { Low } \\
\mathrm{CO}_{2}\end{array}$ & $\begin{array}{l}\mathrm{High} \\
\mathrm{CO}_{2}\end{array}$ \\
\hline Respiratory rate & - & $\begin{array}{r}18 \\
( \pm 4)\end{array}$ & $\begin{array}{l}26^{*} \\
( \pm 3)\end{array}$ & $\begin{array}{l}34^{*} \\
( \pm 4)\end{array}$ \\
\hline Minute volume, liters/min & - & $\begin{array}{r}5.58 \\
( \pm 0.86)\end{array}$ & $\begin{array}{r}14.36^{*} \\
( \pm 1.91)\end{array}$ & $\begin{array}{c}23.06^{*} \\
( \pm 3.07)\end{array}$ \\
\hline \multicolumn{5}{|l|}{ Arterial blood gases } \\
\hline $\mathrm{PaO}_{2}, m m \mathrm{Hg}$ & $\begin{array}{c}90.3 \\
( \pm 2.5)\end{array}$ & $\begin{array}{c}309.8 \\
( \pm 38.5)\end{array}$ & $\begin{array}{r}292.3 \\
( \pm 41.7)\end{array}$ & $\begin{array}{r}281.3 \\
( \pm 40.6)\end{array}$ \\
\hline $\mathrm{PaCO}_{2}, m m \mathrm{Hg}$ & $\begin{array}{c}24.3 \\
( \pm 1.5)\end{array}$ & $\begin{array}{c}29.5 \\
( \pm 1.5)\end{array}$ & $\begin{array}{l}37.3^{*} \\
( \pm 3.3)\end{array}$ & $\begin{array}{l}42.5^{*} \\
( \pm 3.8)\end{array}$ \\
\hline $\mathrm{pHa}$ & $\begin{array}{c}7.41 \\
( \pm 0.03)\end{array}$ & $\begin{array}{r}7.32 \\
( \pm 0.02)\end{array}$ & $\begin{array}{r}7.26^{*} \\
( \pm 0.02)\end{array}$ & $\begin{array}{r}7.21^{*} \\
( \pm 0.03)\end{array}$ \\
\hline \multicolumn{5}{|l|}{$\begin{array}{l}\text { Rate of work of breathing, } \\
\quad(\mathrm{Cal} / \mathrm{min})\end{array}$} \\
\hline Inspiration & 0 & $\begin{array}{r}0.46 \\
( \pm 0.09)\end{array}$ & $\begin{array}{r}1.99^{*} \\
( \pm 0.36)\end{array}$ & $\begin{array}{r}4.09 * \\
( \pm 0.81)\end{array}$ \\
\hline Expiration & 0 & $\begin{array}{r}0.02 \\
( \pm 0.01)\end{array}$ & $\begin{array}{r}0.13 \\
( \pm 0.08)\end{array}$ & $\begin{array}{r}0.28 \\
( \pm 0.15)\end{array}$ \\
\hline Total & 0 & $\begin{array}{r}0.48 \\
( \pm 0.07)\end{array}$ & $\begin{array}{r}2.12^{*} \\
( \pm 0.35)\end{array}$ & $\begin{array}{r}4.37^{*} \\
( \pm 0.98)\end{array}$ \\
\hline
\end{tabular}

Mean \pm SEM

* Significantly changed from resting value $(P<0.05)$. 
the diaphragm. Percent efficiency was estimated as $100 \times$ the rate of work of breathing done on the lung expressed in oxygen equivalents $\left(1 \mathrm{ml} \mathrm{O}_{2} / \mathrm{min}=0.2 \mathrm{Cal} / \mathrm{min}\right)$ divided by the total oxygen consumption of the respiratory muscles.

Statistical analysis was performed by Student's $t$ test for paired or nonpaired mean data, or by linear regressions, where applicable.

\section{RESULTS}

Work of breathing. Table I lists the changes in respiratory rate, minute volume, arterial blood gases, and rate of work (power) of breathing observed on mechanical ventilation, resting ventilation breathing high oxygen content gas mixtures, and low $\mathrm{CO}_{2}$ and high $\mathrm{CO}_{2}$ rebreathing. Compared with resting ventilation, respiratory rate approximately doubled $(P$ $<0.0001)$, minute volume increased approximately fourfold $(P<0.001), \mathrm{PaO}_{2}$ decreased minimally $(P$ $=0.10), \mathrm{PaCO}_{2}$ increased $(P<0.02)$, and $\mathrm{pH}$ fell $(P<0.003)$ at the highest level of $\mathrm{CO}_{2}$ rebreathing. The rate of work of breathing increased approximately ninefold $(P<0.001)$, almost all of which was due to increased inspiratory work $(P<0.001)$. Expiratory work rate increased slightly $(P=0.09)$, but did not make a major contribution to the total.

Blood flow. The blood flow per gram to each of the muscles listed as muscles of respiration in dogs by Miller et al. (14) are indicated in Table II. The muscles whose flow increased significantly are graphed in Fig. 2. Only the flows to the diaphragm and external intercostals increased significantly between mechnical ventilation and resting ventilation $(P<0.02$ for diaphragm, $P<0.03$ for external intercostals). The diaphragm had the largest increases in blood flow per gram $\left(\dot{\mathbf{Q}}_{\mathrm{D}}\right)$, and flow was linearly re-

TABLE II

Blood Flow during $\mathrm{CO}_{2}$ Rebreathing

\begin{tabular}{lcccc}
\hline & $\begin{array}{c}\text { Mechanical } \\
\text { ventilation }\end{array}$ & $\begin{array}{c}\text { Resting } \\
\text { ventilation }\end{array}$ & $\begin{array}{c}\text { Low } \\
\mathrm{CO}_{2}\end{array}$ & $\begin{array}{c}\mathrm{High} \\
\mathrm{CO}_{2}\end{array}$ \\
\hline Inspiratory muscles & & Blood flow, $\mathrm{ml} / \mathrm{g} / \mathrm{min}$ & \\
Diaphragm & $0.04 \pm 0.01$ & $0.09 \pm 0.01^{*}$ & $0.21 \pm 0.02^{*}$ & $0.33 \pm 0.02^{*}$ \\
External intercostals & $0.03 \pm 0.00$ & $0.07 \pm 0.01^{*}$ & $0.14 \pm 0.03^{*}$ & $0.24 \pm 0.05^{*}$ \\
Scalenes & $0.04 \pm 0.02$ & $0.06 \pm 0.02$ & $0.05 \pm 0.02$ & $0.05 \pm 0.02$ \\
Serratus dorsalis & $0.04 \pm 0.02$ & $0.04 \pm 0.01$ & $0.03 \pm 0.01$ & $0.02 \pm 0.00$ \\
Serratus ventralis & $0.05 \pm 0.02$ & $0.04 \pm 0.02$ & $0.03 \pm 0.01$ & $0.03 \pm 0.00$ \\
Expiratory muscles & & & & \\
Transverse ab- & & & & \\
$\quad$ dominal & $0.05 \pm 0.01$ & $0.05 \pm 0.01$ & $0.11 \pm 0.04$ & $0.17 \pm 0.04^{*}$ \\
Internal intercostals & $0.04 \pm 0.01$ & $0.04 \pm 0.01$ & $0.10 \pm 0.03$ & $0.15 \pm 0.05^{*}$ \\
Internal oblique & $0.04 \pm 0.01$ & $0.03 \pm 0.01$ & $0.04 \pm 0.00$ & $0.07 \pm 0.01$ \\
External oblique & $0.03 \pm 0.01$ & $0.03 \pm 0.01$ & $0.03 \pm 0.00$ & $0.04 \pm 0.01$ \\
Rectus abdominis & $0.03 \pm 0.00$ & $0.03 \pm 0.01$ & $0.02 \pm 0.01$ & $0.03 \pm 0.01$ \\
Ileocostalis & $0.04 \pm 0.02$ & $0.04 \pm 0.01$ & $0.03 \pm 0.01$ & $0.04 \pm 0.01$ \\
Controls (grouped) & $0.04 \pm 0.01$ & $0.04 \pm 0.00$ & $0.03 \pm 0.00$ & $0.04 \pm 0.00$ \\
\hline
\end{tabular}

Mean \pm SEM.

${ }^{*}$ Significantly increased from mechanical ventilation $(P<0.05)$.

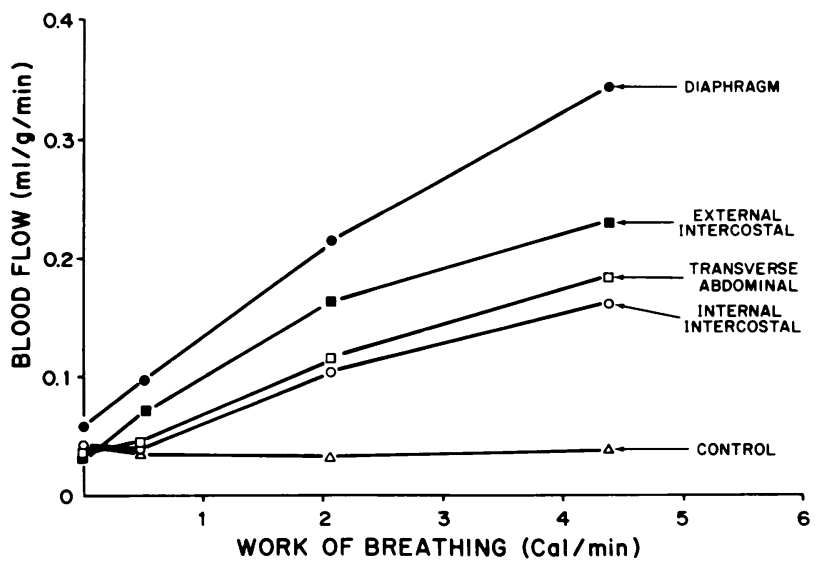

Figure 2 Blood flow per gram to the various muscles of respiration during mechanical ventilation (work rate $=0$ ) and three levels of spontaneous ventilation.

lated to total rate of work of breathing $(\dot{W})$ in calories per minute:

$$
\dot{\mathrm{Q}}_{\mathrm{D}}=0.050 \dot{\mathrm{W}}+0.074, \mathrm{n}=26, r=0.88, P<0.0001 \text {. }
$$

Flow to the external intercostals $\left(\dot{Q}_{\mathrm{E}}\right)$ also was linearly related to rate of work of breathing but with a lower slope:

$$
\dot{\mathrm{Q}}_{\mathrm{E}}=0.032 \dot{\mathrm{W}}+0.057, \mathrm{n}=22, r=0.69, P<0.0001 \text {. }
$$

The scalenes and serratus dorsalis and ventralis, usually considered accessory muscles of inspiration in dogs (14), did not exhibit augmented flows over the range of minute ventilation studies.

The only expiratory muscles which showed an increase in blood flow were the transverse abdominis and internal intercostals, which were significantly increased at the high $\mathrm{CO}_{2}$ level only $(P<0.04$ and $P<0.05$, respectively). Blood flows per gram to control muscles (triceps brachii and pectoralis) did not change.

Total blood flow to each muscle was calculated by multiplying blood flow per gram by the muscle weight. If the respiratory muscles under the condition of $\mathrm{CO}_{2}$ rebreathing are assumed to be those whose flow increased (diaphragm, intercostals, and transverse abdominal), then total blood flow to the muscles of respiration ( $\left.\dot{Q}_{\mathrm{RS}}\right)$ can be calculated (Table III). On mechanical ventilation the diaphragm received $24 \%$ of the total respiratory muscle blood flow $\left(\dot{\mathrm{Q}}_{\mathrm{D}} / \dot{\mathrm{Q}}_{\mathrm{RS}}\right)$, a ratio similar to the percentage $(26 \%)$ the diaphragm contributes to total respiratory muscle weight (1). On resting spontaneous ventilation the fractional blood flow to the diaphragm rose to $37 \%$ $(P<0.03)$. It did not change significantly thereafter as minute ventilation increased due to rebreathing low $(P<0.40)$ or high $(P<0.60)$ levels of $\mathrm{CO}_{2}$. Each of these fractional blood flows was sig- 
TABLE III

Total Blood Flow to Various Respiratory Muscles during $\mathrm{CO}_{2}$ Rebreathing

\begin{tabular}{|c|c|c|c|c|}
\hline & $\begin{array}{c}\text { Mechanical } \\
\text { ventilation }\end{array}$ & $\begin{array}{c}\text { Resting } \\
\text { ventilation }\end{array}$ & $\begin{array}{l}\text { Low } \\
\mathrm{CO}_{2}\end{array}$ & $\begin{array}{l}\mathrm{High} \\
\mathrm{CO}_{2}\end{array}$ \\
\hline & \multicolumn{4}{|c|}{$\mathrm{ml} / \mathrm{min}$} \\
\hline \multicolumn{5}{|l|}{ Total blood flow } \\
\hline Diaphragm $\left(\dot{Q}_{\mathrm{D}}\right)$ & $\begin{array}{r}3.89 \\
( \pm 0.89)\end{array}$ & $\begin{array}{r}8.47 \\
( \pm 1.32)\end{array}$ & $\begin{array}{c}19.64 \\
( \pm 2.52)\end{array}$ & $\begin{array}{r}32.52 \\
( \pm 2.63)\end{array}$ \\
\hline External intercostals & $\begin{array}{r}2.99 \\
( \pm 0.36)\end{array}$ & $\begin{array}{r}4.72 \\
( \pm 0.66)\end{array}$ & $\begin{array}{c}10.62 \\
( \pm 2.29)\end{array}$ & $\begin{array}{r}17.34 \\
( \pm 3.32)\end{array}$ \\
\hline Internal intercostals & $\begin{array}{c}5.33 \\
( \pm 0.70)\end{array}$ & $\begin{array}{r}5.92 \\
( \pm 0.88)\end{array}$ & $\begin{array}{c}14.41 \\
( \pm 4.49)\end{array}$ & $\begin{array}{c}21.12 \\
( \pm 6.49)\end{array}$ \\
\hline Transverse abdominals & $\begin{array}{r}3.99 \\
+( \pm 0.84) \\
\end{array}$ & $\begin{array}{r}4.01 \\
+( \pm 1.10) \\
\end{array}$ & $\begin{array}{r}9.94 \\
+( \pm 3.35) \\
\end{array}$ & $\begin{array}{r}13.08 \\
+( \pm 2.02) \\
\end{array}$ \\
\hline $\begin{array}{c}\text { Total respiratory } \\
\text { muscle }\left(\dot{Q}_{\mathrm{RS}}\right)\end{array}$ & $\begin{array}{c}16.02 \\
( \pm 2.00)\end{array}$ & $\begin{array}{c}23.12 \\
( \pm 2.89)\end{array}$ & $\begin{array}{r}54.61 \\
( \pm 13.56)\end{array}$ & $\begin{array}{r}84.06 \\
( \pm 17.17)\end{array}$ \\
\hline$\dot{\mathrm{Q}}_{\mathrm{D}} / \dot{\mathrm{Q}}_{\mathrm{Rs}}$ & $\begin{array}{c}0.24 \\
( \pm 0.03)\end{array}$ & $\begin{array}{r}0.37 \\
( \pm 0.04)\end{array}$ & $\begin{array}{c}0.36 \\
( \pm 0.04)\end{array}$ & $\begin{array}{r}0.39 \\
( \pm 0.04)\end{array}$ \\
\hline
\end{tabular}

Mean \pm SEM

nificantly greater than the fractional weight that the diaphragm contributes to total respiratory muscle weight $(P<0.01)$.

While these changes in muscle blood flows were occurring, blood pressure (Fig. 3) was not significantly changed $(P<0.36)$ but cardiac output approximately doubled $(P<0.04)$.

Oxygen consumption. The arteriovenous oxygen content difference $\left(\mathrm{A}-\mathrm{V} \Delta \mathrm{CO}_{2}\right)$ is plotted against work of breathing in Fig. 4A and against diaphragmatic blood flow $\left(\dot{Q}_{D}\right)$ in Fig. 4B (open circles, dashed line) for mechanical ventilation (work rate $=0$ ), resting ventilation, low $\mathrm{CO}_{2}$, and high $\mathrm{CO}_{2}$. During this sequence the A-V $\Delta \mathrm{CO}_{2}$ increased steadily, never reaching a plateau at work levels we were able to induce.

Total respiratory muscle oxygen consumption calculated from the product of $\mathrm{A}-\mathrm{V} \Delta \mathrm{CO}_{2}$ and total respiratory muscle blood flow is shown in Table IV. The oxygen consumption $\left(\dot{\mathrm{V}}_{\mathrm{O}_{2}}\right)$ increased linearly with increasing rate of mechnical work of breathing:

$$
\dot{\mathrm{V}}_{\mathrm{O}_{2}}=6.99 \dot{\mathrm{W}}+0.34, \mathrm{n}=12, r=0.95, P<0.0001 \text {. }
$$

The efficiency of the respiratory muscles in doing work on the lung is shown in Table IV. At resting ventilation efficiency was $14.8 \%$. Efficiency did not change significantly $(P=0.39)$ as minute ventilation doubled and quadrupled due to $\mathrm{CO}_{2}$ rebreathing. The mean for all three levels of ventilation was $15.5 \%$.

\section{DISCUSSION}

Blood flow. Our results indicate that blood flow per gram was similar for all respiratory muscles and non- respiratory control muscles during mechanical ventilation (Fig. 2 and Table II). In the transition from mechanical ventilation to spontaneous resting ventilation only the blood flows to the diaphragm and external intercostals increased. This supports the conclusion that quiet breathing is accomplished by active inspiration through contraction of inspiratory muscles and passive expiration by elastic recoil of the lungs and thorax. Our pressure-volume data on the partition of the work of breathing between inspiration and expiration corroborate this finding; expiratory work did not significantly increase in the transition from mechanical ventilation to spontaneous resting ventilation. Goldman and Mead have suggested that contraction of the diaphragm not only expands the lungs downward by simple descent but also indirectly expands the rib cage by increasing abdominal pressure; hence the diaphragm in their view may be doing all of the work during quiet breathing (15). However, our finding of an increase in blood flow to external intercostal muscles as well as to the diaphram in the transition from mechanical ventilation to spontaneous quiet breathing suggests that intercostal muscles as well as the diaphragm participate in quiet breathing in this model.

The larger increase in diaphragmatic than external intercostal flow is compatible with the observations that at rest in the supine position most of the volume change during inspiration occurred in the abdomen, not the rib cage (16-19). Apparently, as ventilation increased this preferential use of the diaphragm for inspiration persisted, as reflected by the fact that diaphragmatic blood flow continued to increase more

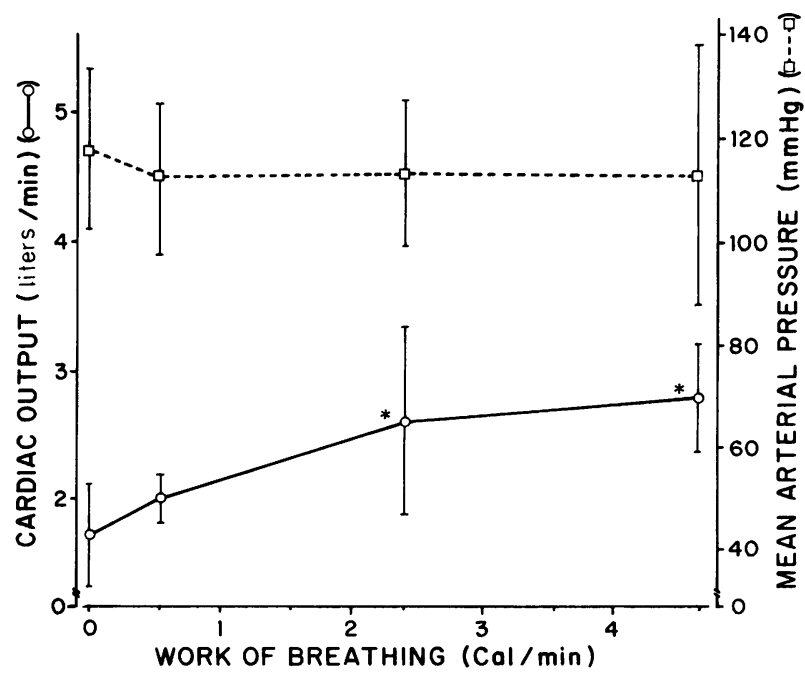

FIGURE 3 Blood pressure and cardiac output for each ventilatory level. Blood pressure did not change, but cardiac output increased significantly at low and high $\mathrm{CO}_{2}$ rebreathing $\left(^{*}, P<0.05\right)$. Bars indicate $\pm 1 \mathrm{SD}$. 

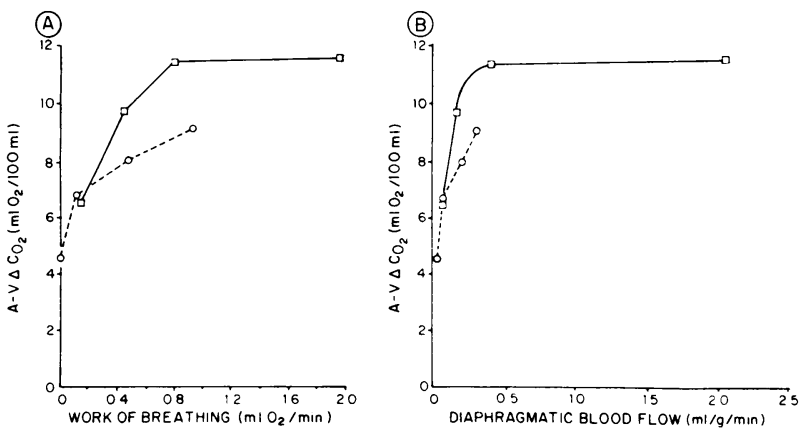

FIGURE 4 The relationship between average arterialdiaphragmatic venous oxygen content difference (A-V $\Delta \mathrm{CO}_{2}$ ) and the rate of work of breathing (A) or diaphragmatic blood flow (B) during $\mathrm{CO}_{2}$ rebreathing $\left(\mathrm{O}_{--} \mathrm{O}\right)$ and inspiratory resistance $(\square-\square)(1)$.

than external intercostal flow. Also, the scalenes did not augment blood flows.

As respiratory rate and tidal volume increased, expiratory pressure-volume work rate increased slightly and blood flows to the two muscles of expiration, the transverse abdominal and internal intercostal, also increased. Thus at higher ventilatory loads the time available for expiration probably was insufficient for passive exhalation by lung elastic recoil, and expiratory muscular effort was necessary.

These changes in muscle blood flow occurred at a constant arterial blood pressure (Fig. 3). Thus, the changes were mediated by local decreases in vascular resistance. The changes were not simply due to the increasing arterial hypercapnic acidosis (Table I) since blood flow to control muscles did not change. Since hypercapnic acidosis is a local vasodilator for skeletal muscle (20), the absence of any rise in blood flow to control muscle suggests that hypercapnic vasodilation was balanced by a reflex increase in limb muscle vascular resistance during increased respiratory muscular effort. A related observation was made in our previous study of distribution of blood flow during inspiratory resistance; as inspiratory resistance and work of breathing increased vascular resistance increased and blood flow decreased in control muscles despite a slight rise in $\mathrm{PaCO}_{2}$ (1). In the present study cardiac output (Fig. 4) increased during hypercapnia more than can be accounted for by the increase in total respiratory muscle blood flow; hence vasodilation must have occurred elsewhere in the body, likely at least to the brain (21), heart (22), and kidneys (22) for which increases in blood flow have been demonstrated during hypercapnea.

We have previously observed a significantly different distribution of blood flow to the individual muscles of respiration under conditions of inspiratory resistance (1). Whereas diaphragmatic blood flow increased linearly with increasing rate of work of breathing dur- ing $\mathrm{CO}_{2}$ rebreathing, during inspiratory resistance diaphragmatic blood flow increased exponentially. Thus, diaphragmatic flows were similar as work of breathing was increased by $\mathrm{CO}_{2}$ rebreathing or by increasing inspiratory resistance as long as ventilatory work rate was less than $4 \mathrm{Cal} / \mathrm{min}$, but above $4 \mathrm{Cal} / \mathrm{min}$ blood flow to the diaphragm was significantly higher with respect to work rate than during $\mathrm{CO}_{2}$-induced hyperventilation. Whereas diaphragmatic blood flow was only moderately greater than external intercostal flow during $\mathrm{CO}_{2}$ rebreathing, diaphragmatic flow increased significantly more than the external intercostal flow during inspiration resistance. Furthermore, at work loads similar to those achieved during $\mathrm{CO}_{2}$ rebreathing, none of the expiratory muscles' blood flows increased during inspiratory resistance.

There are no previous reports of the distribution of blood flow to each respiratory muscle during mechanical ventilation or increased ventilation induced by $\mathrm{CO}_{2}$ rebreathing but there are a few studies which have measured blood flow to the diaphragm and occasionally a few accessory muscles. Rochester and Pradel-Guena, using clearance of ${ }^{133}$ xenon injected into the diaphragm of dogs (23), reported a flow during resting ventilation of $0.42 \mathrm{ml} / \mathrm{g}$ per min which increased to $0.57 \mathrm{ml} / \mathrm{g}$ per min when minute ventilation was doubled by $\mathrm{CO}_{2}$ inhalation. Mognoni et al., using a ${ }^{86} \mathrm{Rb}$ uptake method in rabbits (24), observed a resting diaphragmatic flow of $0.40 \mathrm{ml} / \mathrm{g}$ per min which increased to 0.74 when ventilation increased threefold. Although these blood flows are consistently higher than ours, the slope of the change in blood flow with respect to ventilation is similar to that observed in our experiments. In the Mognoni study blood flow to the scalene muscles and the interchondral part of the external intercostals were unchanged. The lack of change in the scalenes is similar to our results, but we did observe a change in flow to the external intercostals, so either there is a species difference or the interchondral portion of the external intercostals behaves differently than the rest, as these were not separated in our study. Subsequently Rochester, with the Kety-Schmidt tech-

TABLE IV

Oxygen Consumption and Efficiency of the Respiratory Musculature

\begin{tabular}{|c|c|c|c|c|}
\hline & \multicolumn{2}{|c|}{ Without rebreathing } & \multicolumn{2}{|c|}{ Rebreathing at } \\
\hline & $\begin{array}{l}\text { Mechanical } \\
\text { ventilation }\end{array}$ & $\begin{array}{l}\text { Spontaneous } \\
\text { respiration }\end{array}$ & $\begin{array}{l}\text { Low } \\
\mathrm{CO}_{2}\end{array}$ & $\begin{array}{l}\mathrm{High} \\
\mathrm{CO}_{2}\end{array}$ \\
\hline $\mathbb{W}, m l O_{2} / \min$ & - & 0.108 & 0.480 & 0.930 \\
\hline $\mathrm{VO}_{2}, \mathrm{ml} \mathrm{O}_{2} / \mathrm{min}$ & $0.79( \pm 0.20)$ & $1.50( \pm 0.35)$ & $4.47( \pm 2.0)$ & $7.54( \pm 3.2)$ \\
\hline Efficiency & - & $14.8 \%( \pm 2.1)$ & $15.7 \%( \pm 1.9)$ & $16.1 \%( \pm 3.1)$ \\
\hline
\end{tabular}

Mean $\pm S E M$ 
nique (13), revised his estimate of diaphragmatic flow during resting ventilation to $0.20 \mathrm{ml} / \mathrm{g}$ per min, but a doubling of minute ventilation only increased diaphragmatic flow to $0.25 \mathrm{ml} / \mathrm{g}$ per min, a much smaller increase in blood flow than we observed or he had found in the previous study. We are unable to resolve these differences, but the small increase in $\dot{Q}_{D}$ which Rochester reports would have yielded unreasonably high efficiencies in our study. In the latter study Rochester also found that diaphragmatic blood flow increased between mechanical ventilation and resting ventilation, similar to the increase we observed.

Hales used the radioactive microsphere technique to study the blood flow to respiratory muscles in sheep during quiet breathing and during the panting hyperventilation induced by a hot environment (25). $\dot{Q}_{D}$ was $0.17 \mathrm{ml} / \mathrm{g}$ per min during quiet respiration, but this study was performed on unanesthetized animals whose minute volumes were likely greater than ours (26); $\dot{Q}_{D}$ increased to 0.56 with mild heat stress and to 1.72 with severe heat stress. Blood flow to the intercostals (not separated) was 0.07 at rest and increased to 0.29 with severe heat stress. Ventilation was not measured, but the larger increases in $\dot{Q}_{D}$ than intercostal flow are even more marked than we have observed with $\mathrm{CO}_{2}$-induced hyperventilation. Panting may require preferential use of the diaphragm.

Oxygen consumption. During $\mathrm{CO}_{2}$ rebreathing the $\mathrm{A}-\mathrm{V} \Delta \mathrm{CO}_{2}$ increased progressively (circles, dashed line in Fig. 4), never reaching a plateau at the work levels that could be obtained with this method. In contrast, during inspiratory resistance breathing (squares, solid line in Fig. 4) A-V $\Delta \mathrm{CO}_{2}$ increased to a maximum at low levels of work while blood flow increased little; at greater levels of resistance, oxygen delivery was accomplished predominantly by increased blood flow (1). When the low resistance is compared to the low $\mathrm{CO}_{2}$ rebreathing point (approximately equal rate of work of breathing and $\dot{Q}_{\mathrm{D}}$ ), the rebreathing $\mathrm{A}-\mathrm{V} \Delta \mathrm{Co}_{2}$ was significantly lower $(P<0.02)$; and, when the medium resistance is compared to the high $\mathrm{CO}_{2}$ rebreathing point (rebreathing work rate slightly larger and $\dot{Q}_{D}$ slightly less), again the difference is significant $(P<0.01)$.

The $\mathrm{CO}_{2}$ rebreathing pattern is like that demonstrated in limb skeletal muscle whose oxygen extraction and blood flow tend to increase together (2); the inspiratory resistance pattern is similar to the left ventricle which utilizes high oxygen extraction at low work loads and at greater loads increases oxygen delivery predominantly by increased blood flow (27). Inspiratory resistance causes the diaphragm, like the left ventricle, to perform a significant component of isometric effort to generate sufficient pressure to produce flow. It has been demonstrated that high intramuscular pressures during tension development (28) and pinching of arterial supply by fascial planes (29) during isometric contraction inhibit blood flow in skeletal muscle. These factors make lower blood flow and higher oxygen extraction necessary in those two circumstances which require significant isometric contraction, whereas the predominantly shortening work in unobstructed increases in ventilation would allow a more equal distribution of oxygen delivery between extraction and perfusion.

Oxygen consumption increased almost linearly with respect to work of breathing during $\mathrm{CO}_{2}$ stimulation (see equation above). Thus, the efficiency of the respiratory muscles (Table IV) did not change significantly $(P>0.10)$. The mean efficiency was $15.5 \%$. In contrast, during inspiratory resistance there was an exponential increase in oxygen consumption as the rate of work of breathing increased (1). Thus, the efficiency progressively fell from $13.3 \%$ on the low resistance to $4.3 \%$ on the high resistance. The lower efficiency during inspiratory resistance breathing is likely due to the increased metabolic energy necessary to perform isometric tension development which is not reflected in mechanical work output.

Reported estimates of efficiency of breathing during unobstructed hyperventilation in humans have varied widely: McGregor and Becklake (6) found a $3.2 \%$ efficiency, Fritts et al. found a $1-8 \%$ efficiency (30), Otis et al. found a 3.0-7.6\% efficiency (31), and Milic-Emili and Petit found a 19-25\% efficiency (32). These studies have used the change in total body oxygen consumption (33-38) as an index of the increase in respiratory muscle oxygen consumption needed for an increased work of breathing. Since the oxygen consumption of the respiratory muscles in normal subjects is only $1-3 \%$ of total body oxygen consumption (33), small errors in the latter measurement cause large errors in calculated respiratory muscle oxygen consumption. Also, oxygen consumption elsewhere in the body might increase during the stressful conditions of hypernea, as observed in our previous study under conditions of inspiratory resistance (1). Perhaps these factors account for the values in the first three studies being considerably below our estimate by the blood flow times oxygen extraction method of $15.5 \%$. The $19-25 \%$ estimates of efficiency in the study by Milic-Emili and Petit are considerably higher than our results. Since the maximal efficiency of limb skeletal muscle is only $19-25 \%$ (34), and since about one-third of respiratory muscle effort probably is used to accomplish resistive and elastic work done on tissues of the thorax and abdomen which is not measured as work output in calculating efficiency (7), the efficiencies obtained by Milic-Emili and Petit seem too high. Perhaps, as they discussed, their approximation of pressure-volume work output was high. 
Our estimate of efficiency during $\mathrm{CO}_{2}$ rebreathing may be slightly low because in calculating oxygen consumption we have assumed for all muscles of respiration a similar $\mathrm{A}-\mathrm{V} \Delta \mathrm{CO}_{2}$ to that of the diaphragm. However, the $\mathrm{A}-\mathrm{V} \Delta \mathrm{CO}_{2}$ of the diaphragm is a function of blood flow to the diaphragm (Fig. 4B), and blood flows to the other muscles of respiration were lower than that of the diaphragm at all levels of ventilation, so their $\mathrm{A}-\mathrm{V} \Delta \mathrm{CO}_{2}$ may have been lower. When efficiency was recalculated correcting the individual muscle's A-V $\Delta \mathrm{CO}_{2}$ values for muscle blood flow by extrapolation from the mean diaphragmatic blood flow/ $\mathrm{A}-\mathrm{V} \Delta \mathrm{CO}_{2}$ curve, the mean efficiency only increased to $15.9 \%$. Also, if it is assumed that our estimate of $15.5 \%$ is lower than $19-25 \%$ efficiency maximum for skeletal muscle due to this unmeasured work on the chest wall and abdomen, then our estimate has failed to measure $18-38 \%$ of the work done by the respiratory muscles. This range correlates nicely with the range of previous estimates of the percentage of respiratory work required to move the tissues of the thorax and abdomen, from $18-20 \%$ (35) to $34 \%$ (36).

\section{ACKNOWLEDGMENTS}

The authors wish to thank R. W. Olson for his technical assistance and M. L. McConnell for her secretarial assistance in preparation of this manuscript.

These studies were performed in part under a grant from the National Heart and Lung Institute (HL 06296).

\section{REFERENCES}

1. Robertson, C. H., Jr., G. H. Foster, and R. L. Johnson, Jr. 1977. The relationship of respiratory failure to the oxygen consumption of, lactate production by, and distribution of blood flow among respiratory muscles during increasing inspiratory resistance. J. Clin. Invest. 59: 31-42.

2. Kramer, K., F. Obal, and W. Quensel. 1939. Untersuchungen über den Muskelstoffwechsel des Warmblüters. III. Mitteilung. Die Saurestoffaufnahme des Muskels während rhythmischer Tatiqkeit. Pflugers Archiv Gesamte Physiol. Menschen Tiere. 241: 717-729.

3. Hirvonen, L., and R. R. Sonnenschein. 1962. Relation between blood flow and contraction force in active skeletal muscle. Circ. Res. 10: 94-104.

4. Barcroft, H. 1963. Circulation in skeletal muscle. Handb. Physiol. Section 2. Circulation. 2: 1353-1385.

5. Monod, H., and J. Scherer. 1965. The work capacity of a synergic muscular group. Ergonomics. 8: 329-338.

6. McGregor, M., and M. R. Becklake. 1961. The relationship of oxygen cost of breathing to respiratory mechnical work and respiratory force. J. Clin. Invest. 40: 971-980.

7. Otis, A. B. 1964. The work of breathing. Handb. Physiol. Section 3. Respiration. 1: 463-476.

8. Campbell, E. J. M., E. Agostoni, and S. Freedman. 1970. Energetics. In The Respiratory Muscles, Mechanics and Neural Control. W. B. Saunders Co., Philadelphia, Pa. 115-137.
9. Rudolph, A. M., and M. A. Heymann. 1967. The circulation of the fetus in utero. Methods for studying distribution of blood flow, cardiac output and organ blood flow. Circ. Res. 21: 163-184.

10. Domenech, R. J., and J. I. E. Hoffman, M. I. M. Nobel, K. B. Saunders, J. R. Henson, and S. Subijanto. 1969. Total and regional coronary blood flow measured by radioactive microspheres in conscious and anesthetized dogs. Circ. Res. 25: 581-596.

11. Buckberg, G. D., J. C. Luck, D. B. Payne, J. I. E. Hoffman, J. P. Archie, and D. E. Fixler. 1971. Some sources of error in measuring regional blood flow with radioactive microspheres. J. Appl. Physiol. 31: 598-604.

12. Archie, J. P. Jr., D. E. Fixler, D. J. Ullyot, J. I. E. Hoffman, J. R. Utley, and E. L. Carlson. 1973. Measurement of cardiac output with and organ trapping of radioactive microspheres. J. Appl. Physiol. 35: 148-154.

13. Rochester, D. F. 1974. Measurement of diaphragmatic blood flow and oxygen consumption in the dog by the Kety-Schmidt technique. J. Clin. Invest. 53: 1216-1225.

14. Miller, M. E., G. C. Christensen, and H. E. Evans. 1964. Myology. In Anatomy of the Dog. W. B. Saunders Co., Philadelphia, Pa. 131-266.

15. Goldman, M. D., and J. Mead. 1973. Mechanical interaction between the diaphragm and rib cage. J. Appl. Physiol. 35: 197-204.

16. Agostoni, E., P. Mognoni, G. Torri, and F. Saracino. 1965. Relation between changes of rib cage circumference and lung volume. J. Appl. Physiol. 20: 1179-1186.

17. Sant'Ambrogio, G., M. Decandia, and L. Provini. 1966. Diaphragmatic contribution to respiration in the rabbit. J. Appl. Physiol. 21: 843-847.

18. Konno, K., and J. Mead. 1967. Measurement of the separate volume changes of the rib cage and abdomen during breathing. J. Appl. Physiol. 22: 407-422.

19. Mognoni, P., F. Saibene, and G. Sant'Ambrogio. 1969. Contribution of the diaphragm and the other inspiratory muscles to different levels of tidal volume and static inspiratory effort in the rabbit. J. Physiol. 202: 517-534.

20. Kontos, H. A., M. D. Thames, A. Lombana, C. O. Watlington, and F. Jessee, Jr. 1971. Vasodilator effects of local hypercapnic acidosis in dog skeletal muscle. Am.J. Physiol. 220: 1569-1572.

21. Kety, S. S., and C. F. Schmidt. 1948. The effects of altered arterial tensions of carbon and oxygen on cerebral blood flow and cerebral oxygen consumption of normal young men. J. Clin. Invest. 27: 484-492.

22. Daughtery, R. M., Jr., J. B. Scott, J. M. Dabney, and F. J. Haddy. 1967. Local effects of $\mathrm{O}_{2}$ and $\mathrm{CO}_{2}$ on limb, renal, and coronary vascular resistances. Am. J. Physiol. 213: 1102-1110.

23. Rochester, D. F., and M. Pradel-Guena. 1973. Measurement of diaphragmatic blood flow in dogs in Xenon 133 clearance. J. Appl. Physiol. 34: 68-74.

24. Mognoni, P., F. Saibene, G. Sant-Ambrogio, and E. Camporesi. 1974. Perfusion of inspiratory muscles at different levels of ventilation in rabbits. Respir. Physiol. 20: $171-179$.

25. Hales, J. R. S. 1973. Effects of heat stress on blood flow in respiratory and non-respiratory muscles in the sheep. Pfluegers Arch. Eur. J. Physiol. 345: 123-130.

26. Ramsay, A. G. 1959. Effects of metabolism and anesthesia on pulmonary ventilation. J. Appl. Physiol. 14: 102-104.

27. Feinberg, H., A. Gerola, and L. N. Katz. 1960. Effect of changes in blood $\mathrm{CO}_{2}$ level on coronary flow and myocardial $\mathrm{O}_{2}$ consumption. Am. J. Physiol. 199: 349-354. 
28. Hvid, N., and O. Sylvest. 1957. Pressure measurements in striated muscle. Int. Congr. Phys. Med. 2: 151.

29. Gray, S. D., E. Carlson, and N. C. Staub. 1967. Site of increased vascular resistance during isometric muscle contraction. Am. J. Physiol. 213: 683-689.

30. Fritts, H. W., Jr., J. Filler, A. D. Fishman, and A. Cournand. 1959. The efficiency of ventilation during voluntary hyperpnea: Studies in normal subjects and in dyspneic patients with either chronic pulmonary emphysema or obesity. J. Clin. Invest. 38: 1339-1348.

31. Otis, A. B., W. O. Fenn, and H. Rahn. 1950. Mechanics of breathing in man. J. Appl. Physiol. 2: 592-607.
32. Milic-Emili, J., and J. M. Petit. 1960. Mechanical efficiency of breathing. J. Appl. Physiol. 15: 359-362.

33. Otis, A. B. 1954. The work of breathing. Physiol. Rev. 34: 449-458.

34. Asmussen, E., 1964. Muscular exercise. Handb. Physiol. Section 3. Respiration. 2: 939-978.

35. Bergofsky, E. H., G. M. Turino, and A. P. Fishman. 1959. Cardiorespiratory failure in kyphoscoliosis. Medicine (Baltimore). 38: 263-317.

36. Opie, L. H., J. M. K. Spalding, and F. D. Stott. 1959. Mechanical properties of the chest during intermittent positive-pressure respiration. Lancet. 1: 545-551. 